\title{
Structural-mineralogical alterations of sandstones in rock-water and rock-water-oil systems within oil-water contact
}

\author{
Natalya Nedolivko ${ }^{1, *}$ \\ ${ }^{1} \mathrm{PhD}$ in Geological and Mineralogical Sciences, Tomsk Polytechnic University, Tomsk, Russia
}

\begin{abstract}
Structural-mineralogical alterations of sandstones under conditions of natural water-oil interaction within Jurassic sedimentary sequences in south-eastern Nurolsk sedimentary basin (Tomsk Oblast, Western Siberian, petroleum province) depend on their predominance in the fluid system and the dissolution-resedimentation process itself. Oil inflow and associated acid solutions into the reservoir resulted in rockwater disequilibrium: unstable minerals decompose and new stable mineral phases form. Under conditions of oil-filling reservoir, terrigenous reservoir alteration reveals zonal behavior. In the oil saturation zone (rock-water-oil system) solution and secondary mineralization are minimized; in the transition zone of water-oil contact (rock-water-oil and rock-water systems) dissolution is well-developed and accompanied by intensive kaolinitization; in edge water zone (rock-water system) no dissolution and predominating quartz-carbonate cementation.
\end{abstract}

\section{Introduction}

Rock-water-oil system constitutes an integral part of the widely-distributed rock-water system on the Earth. On the one hand, this system is related to the sweeping processes between water and rock-sediments buried during sedimentogenesis and altered during catagenesis; on the other hand, the sweeping process in the reservoir during the migration of hydrocarbons of the oil sequence and the formation, generation and disintegration of the reservoirs. The article discusses the structural-mineralogical alterations of sandstones in layer-arch reservoir traps, oil-filled not to spill, generating oil-water contact (OWC), involving oil-water transition zones of different thicknesses.

The following research methods were applied: petrographic (secondary rock alteration behavior), thermo-X-ray luminescent (feldspar alteration), infrared spectroscopy (pyrite alteration), X-ray diffraction (feldspar, carbonates) and microprobe analysis (carbonates).

Research target includes Tumen formation $\left(\mathrm{J}_{2} \mathrm{tm}\right)$ sand sediments, exposed by drilling Gerasimovskoe oil-gas-condensate field (south-eastern Nurolsk sedimentary basin in Western Siberian oil-gas bearing province, Tomsk Oblast), where bottom water forming

\footnotetext{
*Corresponding author: nedolivko@tpu.ru
} 
OWC underlies the oil reservoir. Stadial rock alteration level is related to catagenesis of $\mathrm{MK}_{2-3}$ gradation.

Allothigenic (quartz, feldspar) and authigenic (carbonates, kaolinite, pyrite) minerals were examined in different thicknesses of the sand reservoirs, which reflected the most contrasting rock alteration processes under formation conditions of the oil reservoir within rock-water and rock-water-oil systems.

\section{Results and discussion}

Reservoir formation in Jurassic sedimentary sequences is associated with successive pulsed oil inflow into the reservoir trap, conditioned by superimposed-epigenetic structuralmineralogical zonation resulting from rock-water- inflow oil interaction [1].

Sandstones-unaffected by the oil reservoir (rock-water system), i.e. embracing background alterations including rock-forming composition of greywacke arkoses, where quartz and feldspar (albite, microcline, orthoclase) predominate over rock fragments (hornstone, felsic and intermediate volcanic rocks / effusive, pegmatites), mica and chlorite. Quartz is heterogeneously decomposed and isolated recomposed.

Feldspar is substituted by pelite and sericite (more than 50\%). Based on X-ray fluorescence analysis including luminescence range of 400-470 $\mathrm{mn}$, reflecting the crystalline defects in $\mathrm{SiO}_{4}{ }^{3-}$ and $\mathrm{AlO}_{4}{ }^{4-}$, the luminescence range of maximal $570 \mathrm{mn}$ and 700 $\mathrm{mn}$ was observed in the X-ray fluorescence spectrum, being characteristic of impurity cations $\mathrm{Mn}^{2+}$ and $\mathrm{Fe}^{3+}$, conditioned by hydromication.

Polymineral cement includes practically-optically visible argillaceous mineral composition: $55-78 \%$ - monocline kaolinite $(7.08 ; 4.34 \AA$ ) $) ; 5-22 \%$ - chlorite $(14.1 ; 7.08$; $4.72 ; 3.56 \AA$ Á); $23-45 \%$ - hydromica $(10.04 ; 4.98 ; 3.34 \AA$ ) $)$ with quartz impurities and sometimes carbonates (siderite and calcite) and pyrite.

Microcrystalline siderite modification includes $\mathrm{FeCO}_{3}$ (53.9-55.0\%), $\mathrm{MnCO}_{3}$ (2.1$3.2 \%), \mathrm{MgCO}_{3}(26.0-32.7 \%)$ and $\mathrm{CaCO}_{3}(10.2-17.0 \%)$ and specified by structural defects (plane reflection on X-ray pattern $k X=2.792-2.798$ ).

Carbonates include $\mathrm{CaCO}_{3}-93.3-94.2 \% ; \mathrm{FeCO}_{3}-1.8-5.0 \% ; \mathrm{MgCO}_{3}-1.7-2.4 \%$; $\mathrm{MnCO}_{3}-1.2-2.1 \%$ related to calcite $(k X=2.99-3.03)$ with defect and perfect structure; including $\mathrm{FeCO}_{3}-7.3-8.7 \%$; $\mathrm{MgCO}_{3}-28.8-31.4 \% ; \mathrm{MnCO}_{3}-0-0.9 \% ; \mathrm{CaCO}_{3}-60.4-$ $62.0 \%$ - related to iron-magnesium-calcium dolomite $(k X=2.89-2.92)$.

Pyrite is characterized by random structure involving relation of intensive peak reflection $210 / 220: 211 / 220: 220 / 2201.68: 1: 1 ; 1.52: 1: 1 ; 1.68: 1: 1 ; 1.71: 1: 1$, i.e A $(36-37 \mathrm{mn})$ $>\mathrm{B}(40-42 \mathrm{mn})$ and $\mathrm{C}(47-48 \mathrm{~nm}), \mathrm{B}=\mathrm{C}$ and, according to genesis, is diagenetic.

Pore space embraces poor touching intergranular pores of different shapes. Porosity is $4.9-10.4 \%$ and permeability - less than $(0.1-0.6) \cdot 10^{-3} \mu \mathrm{m}^{2}$.

According to the characteristic features of fluid saturation and structural-mineralogical rock alteration, three zones were identified in the formation cross-section, successively downward: 1 - oil saturation zone and capillary bound water (rock-water-oil system); 2 OWC transition zone including mobile oil and water: $2 \mathrm{~A}$ - upper subzone with mobile oil and water (rock-water-oil system); $2 \mathrm{~B}$ - bottom subzone with mobile water (rock-water system); 3 - discharge zone of water solutions (rock-water system).

Pore water, saturated by unaffected by the oil reservoir rocks exhibits poor alkaline character and is in equilibrium with carbonate and other mineral rocks [2].

Sandstones, from oil saturation zone and capillary bound water (rock-water-oil system) zones, are sensitive to oil intrusion and its associated water fluids into pore spaces.

Quartz is poorly dissolved on the periphery of the zone and sometimes locally degenerated. 
Feldspar is dissolved on the periphery and inside the grain (along cleavage crack), being replaced by pelite (kaolinite) and sericite (hydromica) to various extent (up to 25\%). Dissolution and hydromicatization are reflected on the X-ray fluorescence spectrum as increased concentration and high (25 units) structure defect intensity $\left(\mathrm{SiO}_{4}{ }^{3-}\right.$ and $\left.\mathrm{AlO}_{4}{ }^{4-}\right)$, corresponding to band $\mathrm{O}^{2-}$ within $400-470 \mathrm{mn}$ range. Hydromicatization is recorded as intensive (up to 50 units) luminescence of impurity defects $\mathrm{Fe}^{3+}$ (maximal luminescence $710 \mathrm{mn}$ ) and $\mathrm{Mn}^{2+}$ (maximal - $570 \mathrm{mn}$ ).

Comparable to siderite sandstones, oil-unaffected siderite itself, involving an average content of $\mathrm{FeCO}_{3}$ (48.6-57.8\%), increased $\mathrm{MgCO}_{3}$ (37.0-46.7\%) content and decreased content of $\mathrm{CaCO}_{3}(3.4-4.4 \%)$ and $\mathrm{MnCO}_{3}(0.6-1.4 \%)$ could be observed. In dolomites $(k X=$ 2.88-2.90) iron $\left(\mathrm{FeCO}_{3}-7.8-10.3 \%\right)$ and magnesium (31.9-36.7\%) content insignificantly increased, while $\mathrm{Mn}\left(\mathrm{MnCO}_{3}-0-0.3 \%\right)$ and especially $\mathrm{Ca}\left(\mathrm{CaCO}_{3}-53.0-57.9 \%\right)$ content decreased. Pure calcite could not be observed in this zone.

According to the peak intensity 210/220:211/220:220/220 and increasing reflection intensity B $(1.39: 1.17: 1 ; 1.63: 1.22: 1 ; 1.917: 1.21: 1 ; 1.55: 1.1: 1 ; 1.85: 1.1: 1)$, i.e. A (36-37 $\mathrm{mn})>\mathrm{B}(40-42 \mathrm{mn})>\mathrm{C}(47-48 \mathrm{~nm})$, it could be concluded that pyrite showed a rather perfect regularity and epigenic nature.

Cement, in combination with undissolved chlorite-hydromica-kaolinite, exposes uniformly thinned (less than 0.002-0.005 $\mathrm{mm}$ ) decrystalline kaolinite.

Void space in oil-containing sandstones involves residual sedimentagenous and diagenetic pores, secondary pores in fragments (surface and interstitial grains), micrograins in recrystalline kaolinite cement. Porosity is $9.4-11.8 \%$, and permeability - (7.910) $\cdot 10^{-3} \mu \mathrm{m}^{2}$.

Under conditions of oil-filling trap, rock-water system transforms into rock-water-oil system. Under the action of acid water, accompanied by migrating oil and containing organic acids and different gases $\left(\mathrm{CO}_{2}\right.$ and $\left.\mathrm{H}_{2} \mathrm{~S}\right)$ [3, 4], alkaline environmentally resistant carbonates, feldspar and partially quartz dissolve. Chemically pure calcite dissolves completely, while isomorphously substituted siderites are deprived of $\mathrm{Ca}^{2+}$ and $\mathrm{Mn}^{2+}-$ predominately mobile cations.

In the dissolution process of carbonates, feldspar and quartz, detached water is enriched by $\mathrm{SiO}_{2}$ and different cations, including $\mathrm{Ca}^{2+}, \mathrm{Mg}^{2+}, \mathrm{Al}^{3+}, \mathrm{Mn}^{2+}, \mathrm{Fe}^{2+}$. Under difficult water exchange conditions, one components $\left(\mathrm{Mn}^{2+}, \mathrm{Fe}^{2+}\right)$ are found in pelite and sericite, substituting feldspar; other components $\left(\mathrm{SiO}_{2}, \mathrm{Al}^{3+}, \mathrm{Fe}^{2+}\right)$ form new mineral phases (quartz, kaolinite, pyrite). Some elements remain dissolved and new oil portions migrate progressively into the lower reservoir layer.

Both sandstones from the transient WOC zone and mobile oil and water in the rock- oilwater system embrace intensive dissolution and secondary mineralization. Subzone 2A (rock-water-oil system) is characteristic of pyrite- kaolinite and 2B (rock-water system) kaolinite secondary mineralization.

Quartz is dissolved and reveals thinly-waved surface, no regeneration.

Feldspar are intensively dissolved (50-55\%) and substituted by kaolinite and sericite. As a result of secondary mineralization, the X-ray fluorescence spectrum reflected intensive luminescence of structural defects (center -type $\mathrm{O}^{2-}$ ) and increasing intensive luminescence of impurity defects $\mathrm{Fe}^{3+}(710 \mathrm{mn})$ and $\mathrm{Mn}^{2+}(570 \mathrm{mn})$.

Only siderite can be found in carbonates opposed to the siderite in the oil-saturated zone, embracing increased iron content $\left(\mathrm{FeCO}_{3}-61.3-63.5 \%\right)$ and low content of magnesium $\left(\mathrm{MgCO}_{3}-33.3-34.4 \%\right)$, calcium $\left(\mathrm{CaCO}_{3}-3.0-3.2 \%\right)$ and manganese $\left(\mathrm{MnCO}_{3}\right.$ $-0-0.7 \%)$.

Epigenic pyrite, closely associated with oxidized bituminous substance, can be found in the subzone 2A. It has a well-ordered structure with peak intensity of 
$210 / 220: 211 / 220: 220 / 220$ to $1.23: 1.28: 1 ; 1.38: 1.36: 1 ; 1.83: 1.80: 1$ relation, and, where $\mathrm{A}$ (36-37 mn) and $\mathrm{B}(40-42 \mathrm{mn})>\mathrm{C}(47-48 \mathrm{mn})$, while $\mathrm{A} \approx \mathrm{B}$.

Kaolinite forms largely monomineral cement, exhibiting coarse-flaky texture (up to 0.06-0.1 $\mathrm{mm}$ ), pseudohexagonal habit and perfect triclinic lattice.

Pore space is the result of rejuvenated dissolution of residual sedimentagenous and diagenetic intergranular and intragranular pores, as well as newly-formed micro-pores on the surface and within fragments and micro-pores in kaolinite cement.

Porosity is $14.1-15.6 \%$ and permeability $-17.7-20.5 \cdot 10^{-3} \mu \mathrm{m}^{2}$.

In the upper subzone (2A) WOC (rock-water-oil system) oil and water are continuously in proximate contact and interaction. Anaerobic oxidized sulfur-reducing oil bacteria transforms into bitumen, in which, at the expense of the consolidation of water-dissolved $\mathrm{Fe}^{2+}$ and liberated sulfur from sulphate, pyrite is formed $\left(\mathrm{FeS}_{2}\right)$. Formed acid solutions intensively dissolve fragments and cement, resulting in the fact that calcite and dolomite fade out of the system, while siderite is free of soluble impurity cations. Kaolinitization $\left(\mathrm{Al}_{2} \mathrm{Si}_{2} \mathrm{O}_{5}(\mathrm{OH})\right.$ intensifies due to kaolinite synthesis from enriched $\mathrm{Al}^{3+}$ solutions [4].

In the bottom subzone (2B) WOC (rock-water system), where circulating acid waters enter into subzone $2 \mathrm{~A}$, pyrite does not form. However, intensive rock dissolution and formation of monomineral kaolinite cement continues.

Cementation zone is formed in sandstones located in water solution discharge zones (rock-water system), where increased amount of secondary quartz and carbonates are identified.

Quartz is formed on clastic grains with regenerated hems and sometimes even boundaries of 0.006 to $0.02 \mathrm{~mm}$ thickness.

Carbonates corrode quartz, substitute feldspar and compose cement. X-ray fluorescence spectrum of feldspar-substituted calcite exhibited weak structural defects of $\mathrm{SiO}_{4}{ }^{3-}$ and $\mathrm{AlO}_{4}{ }^{4-}$ and intensive luminescence of maximal $620 \mathrm{mn}$, which is characteristic of $\mathrm{Mn}^{2+}$, found in carbonates.

Comparable to siderite in the dissolution zone, this siderite exhibits decreased iron content $\left(\mathrm{FeCO}_{3}-59.3-61.5 \%\right)$ and magnesium $\left(\mathrm{MgCO}_{3}-25.5-26.8 \%\right)$, and increased content of calcium $\left(\mathrm{CaCO}_{3}-9.0-9.3 \%\right)$ and manganese $\left(\mathrm{MnCO}_{3}-4.0-4.7 \%\right)$. Based on the IR spectroscopy, siderite spectrum reflected additional absorption bands, while reflection C-O relation resolved in the range of significantly high frequency shifts towards $868 \mathrm{~cm}^{-1}$. Calcite includes $\mathrm{CaCO}_{3}-52.5-58.4 \% ; \mathrm{MgCO}_{3}-28.9-38.9 \%, \mathrm{FeCO}_{3}-4.9-10.4 \%$, $\mathrm{MnCO}_{3}-0.3-1.2 \%$. According to the peak location on the IR spectroscopy in the range of $860-880 \mathrm{~cm}^{-1}$, and associated with deformation vibrations of $\mathrm{C}-\mathrm{O}$ relation, calcite is isomorphously substituted $\left(872 \mathrm{~cm}^{-1}\right)$. Reflection shift in the area of significantly low frequency $\left(863-871 \mathrm{~cm}^{-1)}\right.$ is associated with the isomorphic penetration of cations $\mathrm{Mg}^{2+}$ and $\mathrm{Fe}^{2+}$ into calcite lattice. More ferrous carbonates deposit close to the oil-bearing contour, while more magnesian carbonates form farther from the contour.

With distance from WOC, water-oxidation products cease to interact with water, acid intensity of solution occurs both in neutral conditions and alkaline environment, while in the hydrodynamic closed rock-water system successive secondary quartz deposition $[5,6]$ and isomorphically substituted carbonates occur.

Research results illustrated in Table 1 
Table 1. Structural-mineralogical alterations of sandstones in rock-water and rock-water-oil systems within generating oil-water contact zones.

\begin{tabular}{|c|c|c|}
\hline $\begin{array}{c}\text { Zone / } \\
\text { Subzone }\end{array}$ & System & Transformations \\
\hline 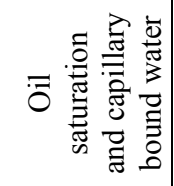 & 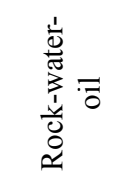 & $\begin{array}{l}\text { Rock: limited dissolution processes, substitution (feldspar) and } \\
\text { mineralization (quartz, kaolinite), predominate intragranular pores. } \\
\text { Water: blending alkaline (porous) water and acid water (migrating and } \\
\text { resulting from oil oxidation). } \\
\text { Oil: limited oxidation on pore (interstitial) water contact. }\end{array}$ \\
\hline 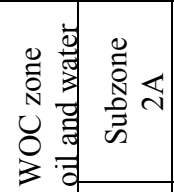 & 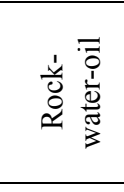 & $\begin{array}{l}\text { Rock: intensive dissolution, substitution, mineralization (pyrite, } \\
\text { coarse-grained kaolinite), well-represented by intragranular, } \\
\text { intergranular and surface pores and micro-pores in kaolinite cement. } \\
\text { Water: acid due to oil oxidation. } \\
\text { Oil: oxidation and bituminization. }\end{array}$ \\
\hline 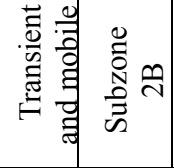 & 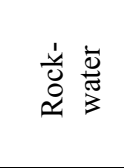 & $\begin{array}{l}\text { Rock: intensive dissolution, substitution and mineralization (coarse- } \\
\text { grained kaolinite), well-represented by intragranular, intergranular and } \\
\text { surface pores and micro-pores in kaolinite cement. } \\
\text { Water: acid hostile solutions in subzone } 2 \mathrm{~A} \text {. }\end{array}$ \\
\hline 㐫 & 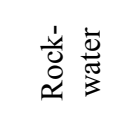 & $\begin{array}{l}\text { Rock: quartz synthesis and isomorphic carbonate substitution, no } \\
\text { developed porosity. } \\
\text { Water: decreasing acidity and increasing alkalinity. }\end{array}$ \\
\hline
\end{tabular}

\section{References}

1. I.A. Melnik, Geophys., 1 (2012)

2. N. Nedolivko, International Geological Congress, Resumes 33 - Norway, Oslo, International Union of Geological Sciences 2090577 (2003)

3. L.A Kalsen, J.E. Skeil, K.B. Owe, K. Bjørlikke, R. Ostad, K. Berge, M. Cecchi, E. Vik, R.G. Sheafer, Understanding Petroleum Reservoirs: Towards an Integrated Reservoir Engineering and Geochemical Approach. Spec.-Publ. , 237 (2004)

4. J. Cao, W. Hu, X. Wang, D. Zhu, Y. Tang, B. Xiang, M. Wu, Geofluids (2015)

5. S.A. Barclay, R.H. Worden, Spec. Publ. Int. Ass. Sediment, 29 (2000)

6. R.H. Worden, N.H. Oxtoby, P.C. Smalley, Petrol. Geosc., 4 (1988) 